\title{
往復式及び回転式シェーバーによる人工毛切断挙動観察
}

野老山 貴行 ${ }^{* 1}$, 中西 直哉 ${ }^{* 2}$, 梅原 徳次 ${ }^{* 3}$

\section{The cutting behaviour observation of the artificial hair by oscillation and rotation shaver}

\author{
Takayuki TOKOROYAMA $^{* 1}$, Naoya NAKANISHI ${ }^{* 2}$ and Noritsugu UMEHARA*3 \\ ${ }^{* 1}$ Faculty of Engineering Science, Akita University \\ 1-1 Tegata-Gakuenmachi, Akita 010-8502, Japan \\ ${ }^{* 2,}{ }^{* 3}$ Department of Mechanical Science and Engineering, Nagoya University \\ 1 Furo-cho, Chikusa-ku, Nagoya 464-8603, Japan
}

\section{Received 21 April 2016}

\begin{abstract}
The shaver is a popular electronic utility for male to cut their beard, hair and so on. It is roughly divided two shaving system as oscillating or rotating motion of an inner blade. The cutting hairs mechanism is also assumed that inner blade edge just cut hairs at the moment of contact between inner blade and hairs. However, the hairs were likely to pull into the shaver and a pulling force generated which we felt in use. The detail cutting motion and pulling force was observed and measured to clarify the differences between oscillation and rotation type by a high speed camera. Each shaving system showed same tendency that the inner blade penetrated to the hair at the first, then both the inner blade and hair moved together to the outer blade. Finally, the inner and outer blade cut the hair by scissor action with pulling force generation simultaneously. As regards oscillation shaver, it was indicated that the inner blade hit the hair several times before the hair was completely cut. The maximum pulling force was approximately $0.15 \mathrm{~N}$ and the average was 0.04 which was higher than rotation type of $0.13 \mathrm{~N}$ as maximum and $0.03 \mathrm{~N}$ as average. Finally, the relation between the inner blade speed and pulling force of rotating type shaver was investigated, and the rotating type showed lower pulling force generation nevertheless of its lower inner blade speed $(1.18 \mathrm{~m} / \mathrm{s})$ than oscillation type $(2.3 \mathrm{~m} / \mathrm{s})$.
\end{abstract}

Key words : Shaver, Inner blade, Outer blade, Artificial hair, Pulling force

\section{1. 緒言}

シェーバーは皮膚表面の髪，毛及び䯿を切断除去するための刃物を有し，特に電動式の場合の名称として用い られている(他にも電動カミソリ, 電気シェーバーなど多くの類似名称が存在している). シェーバーには外刃 (皮 膚に当たる部分で無数の小さな穴の開いた金属板）及び内刃（外刃の裏側で往復もしくは回転運動する刃）があ り，モータの動力により動作する．外刃金属板の穴からシェーバー内部に入った髭は，内部へ引っ張られながら 切断される状態になるため, 使用者は鬍が引き込まれる力（場合によっては痛み）を感じる. 切断後の鬍は皮膚 の毛穴内に少し入り込み，毛先が飛び出すことが少なく，シェービング後の皮膚がなめらかになる．人間の髡や 髪の毛は外側にキューティクルと呼ばれる外皮部分と中心にコルテクスと呼ばれる水分や栄養分を供給しながら 徐々に成長していくタンパク質部分に分けられ（佐藤，2006）（景山，飯村，2009），外側のキューティクル部分 の厚みは約 $0.5 \mu \mathrm{m}$ の硬い非ケラチンタンパク質が 5 から 10 層重なった構造で, 引張強度が約 $43 \mathrm{MPa}$ と報告され ており（井上他，2006），例えば $\mathrm{ABS}$ 樹脂や，ポリエチレンなどと同程度である. シェーバーの切れ味評価方法 として JIS-C9614 が定められており（日本工業規格，1995)，アクリルを主成分とした人工毛をシェーバー内に挿

\footnotetext{
No.16-00187 [DOI: 10.1299/transjsme.16-00187], J-STAGE Advance Publication date : 22 November, 2016

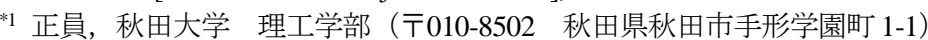

*2 名古屋大学 工学部（干464-8603 愛知県名古屋市千種区不老町 1)

*3 正員, フェロー, 名古屋大学 工学部

E-mail of corresponding author: tokoroyama@gipc.akita-u.ac.jp
} 
入して切断し, 人工毛断部の伸長長さが $0.4 \mathrm{~mm}$ 未満の状態を“良”として良断面本数率を算出する方法である. 従来では，人工毛の引き込み力測定は人間の手動によって行われ，引き込み力を数值化できていない，測定者に よって引き込み力の有無を判断する基準がばらついているなどの問題点があった. 引き込み力が大きいと使用者 は痛みを感じるため,引き込み力が小さくかつ切れ味のよいシェーバーが求められている.内刃の動作形態には, 大きく分けて回転式と往復式の 2 種類がある. 回転式シェーバーは一方向にドラム状の刃が一定速度で回転する ことで髭を切断している，一方，往復式シェーバーは一定の振幅を刃が往復することにより髭を切断している方 式である. 著者らはこれまでに一方向に回転する内刃の先端曲率半径が人工毛の切断時にシェーバー内部へと引 き込む力と, 切断状態の関係を明らかにしてきた（Tokoroyama et al., 2007). 先端曲率半径が大きくなることで切 断時の引き込み力が大きくなることなどが明らかになったが，一定速度で回転し髼を切断する回転式シェーバー に対し, 往復式シェーバーの鬍切断形態及び引き込み力は明らかにされていない. 往復式シェーバーの場合, 内 刃の速度がゼロになる瞬間があり, 切れ味及び髸のシェーバー内部への引き込み力が一定でないと推測される. そこで, 本研究では, 往復式シェーバーを用い, 人工毛切断時に発生する引き込み力に及ぼす内刃速度の影響に ついて明らかにする. 内刃が人工毛を切断する際の様子を高速度カメラにより撮影し, 回転式及び往復式シェー バーの切断時の違いについて明らかにした.

\section{2. 実験方法及び試作装置}

\section{$2 \cdot 1$ 引き込み力測定実験装置及び人工毛}

人工毛のシェーバー内への引き込み力を測定するため, 人工毛を貼付け可能なロードセル, シェーバーの姿勢を維 持可能な自在アームをそれぞれベースとなる金属板に固定した装置を試作した. 実験装置の外観写真を図 1 (a) に装置 模式図を（b）に示寸．回転式及び往復式シェーバーは，人工毛をシェーバー外刃の穴内部に平行に挿入するため それぞれ自在アームに固定され, 出力電圧及び電流を任意に調節可能な直流安定化電源に接続されている. シェ 一バー外刃の髮の入る穴に対し，垂直に人工毛を挿入可能で，挿入深さを任意に調節できるように，ロードセル

（共和電業 : LVS-5GA）をX 軸ステージに固定した. 人工毛はロードセルに直接粘着テープにより固定されてい る. 人工毛がシェーバー内に挿入される場合のガイド用に内径約 $0.6 \mathrm{~mm}$ の注射器用針を配置し, 引き込み力を 測定した。試験機は回転式シェーバー(RM-GTX1)及び往復式シェーバー(ES-LA94)を用いた．回転式シェーバー の内刃外観写真を図 2 (a) に, 外刃外観写真を図 2 (b) に示寸. 回転式シェーバーの内刃は円筒状の側面部に刃

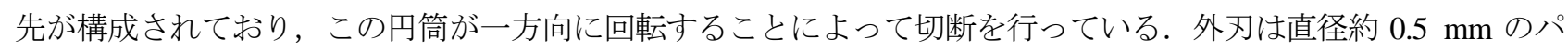
ンチングメタルのような穴が無数に存在して構成されている.切断時に外刃は動かず, 内刃のみが回転している. 同様に往復式シェーバーの内刃を図 3 （a）に，外刃を図 3 (b) に示す. 往復式シェーバーの内刃はアーチ形をし ており, 往復しゅう動して切断を行う. 外刃は回転式シェーバーと同様に約 $0.5 \mathrm{~mm}$ の穴が無数に存在して構成
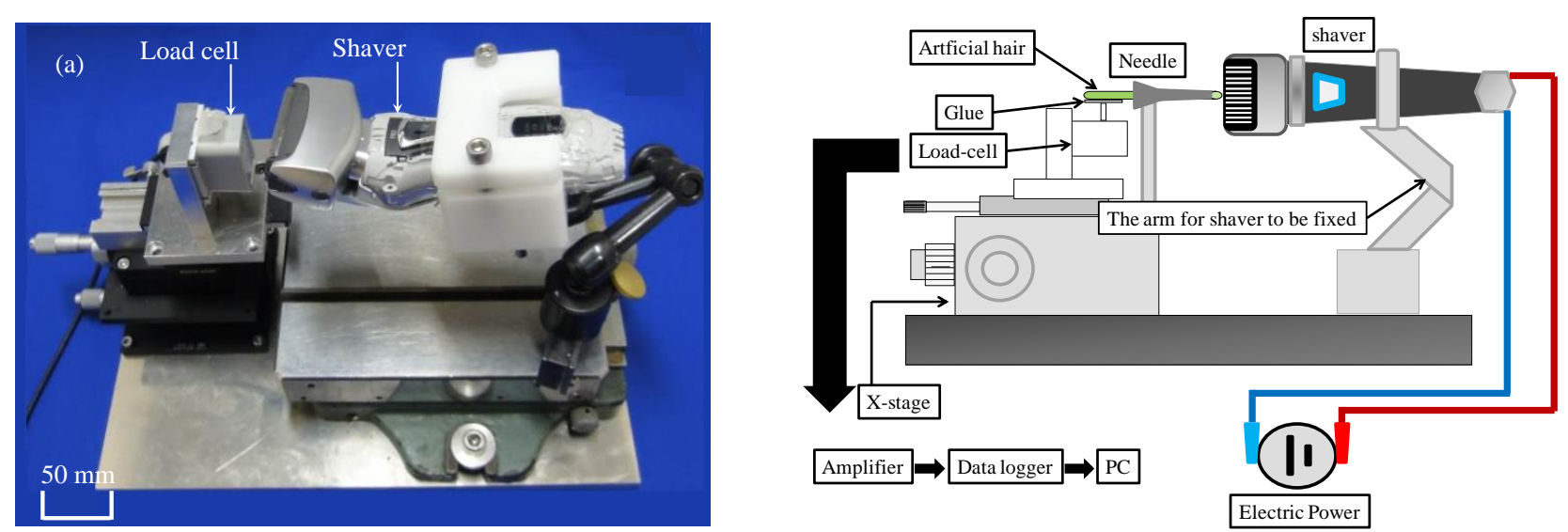

Fig. 1 The experimental equipment of pulling force measurement as shown in (a) as the picture and (b) as schematic image. The shavers were clutched by plastic attachment which was fixed to the universal arm. The artificial hair which is consisted of nylon was set on the load cell by double glue tape, and the load cell was equipped onto the X-stage. The artificial hair was pushed through guide needle and the hair penetrated into the shaver of the outer blade hole. The penetration depth was adjusted before the measurement start. 
されており，髭の切断時には外刃は動かない.いずれの内刃も約 $30^{\circ}$ の先端角度である（図 4 (a) 及び（b)）。 また，いずれの内刃の先端も先端曲率半径約 $11 \mu \mathrm{m}$ である.

試験用材料として，ナイロンの人工毛を用いた。 ナイロンの代表的な物質值を表 1 に示す. ナイロンを人工毛 として扱い，任意の長さに切断後ロードセルに設置して実験を行った.

シェーバーに直流外部電源を接続し電圧を調節することで, 刃先速度を変化させて切断実験を行った。また， 切断時に発生する引き込み力と刃先が人工毛に接触して切断するまでの様子をその場観察するため, 高速度力メ ラを用いて撮影を行った. 実験開始前に人工毛をシェーバー内に約 $0.5 \mathrm{~mm}$ 挿入して電源を投入し，人工毛を切 断するが，人工毛の挿入前に内刃と外刃の位置を確認し，電源投入直後に内刃が人工毛を切断可能であることを 毎回予め確認して実験を行った。切断実験はいずれのシェーバーに対しても 7 回ずつ行い，得られた最大值と， 各最大值の平均を結果として得た。切断後の人工毛形状の観察には電子顕微鏡（ニコン社製，ESEM-2000）が用 いられた. シェーバーへの電源投入後，シェーバー内のモータ回転に伴う振動が引き込み力測定に影響を及ぼす 懸念があったが, 後述する実験結果において, 内刃が接触していない状態で引き込み力への振動ノイズはほとん ど無いことが確認されている.
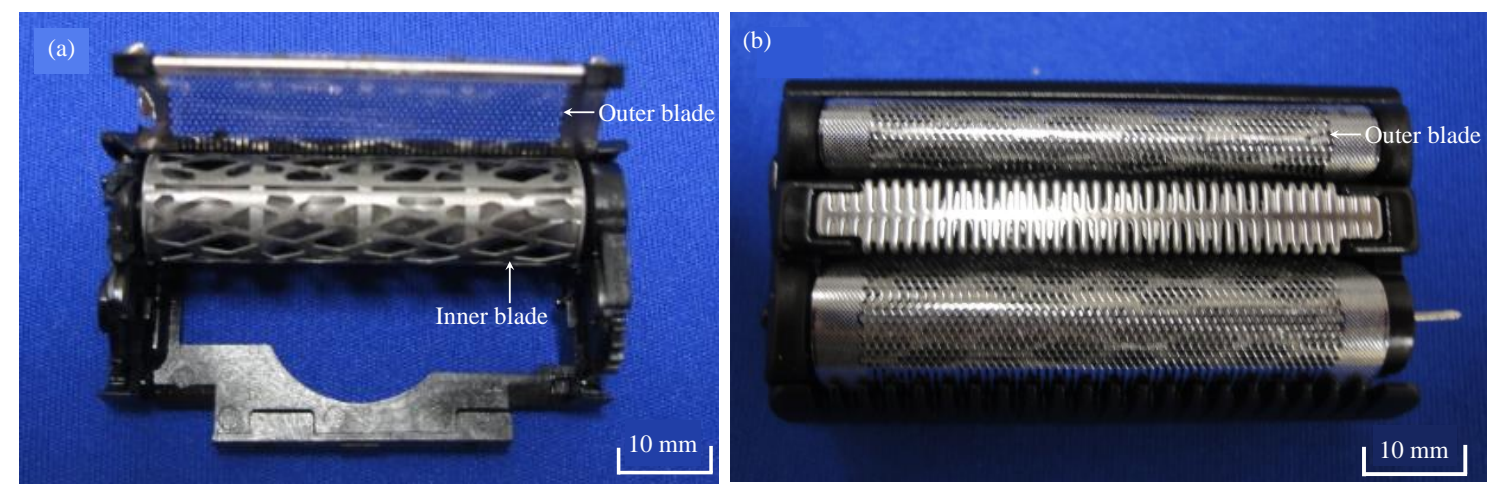

Fig. 2 The picture of rotary type shaver of (a) inner blade and (b) outer blade. This type has cylinder with several edges on the side of the cylinder as inner blade which rotate to cut the hair. The outer blade is like punching metal which has approximately $0.5 \mathrm{~mm}$ diameter of holes. The outer blade does not move when it cut hairs.
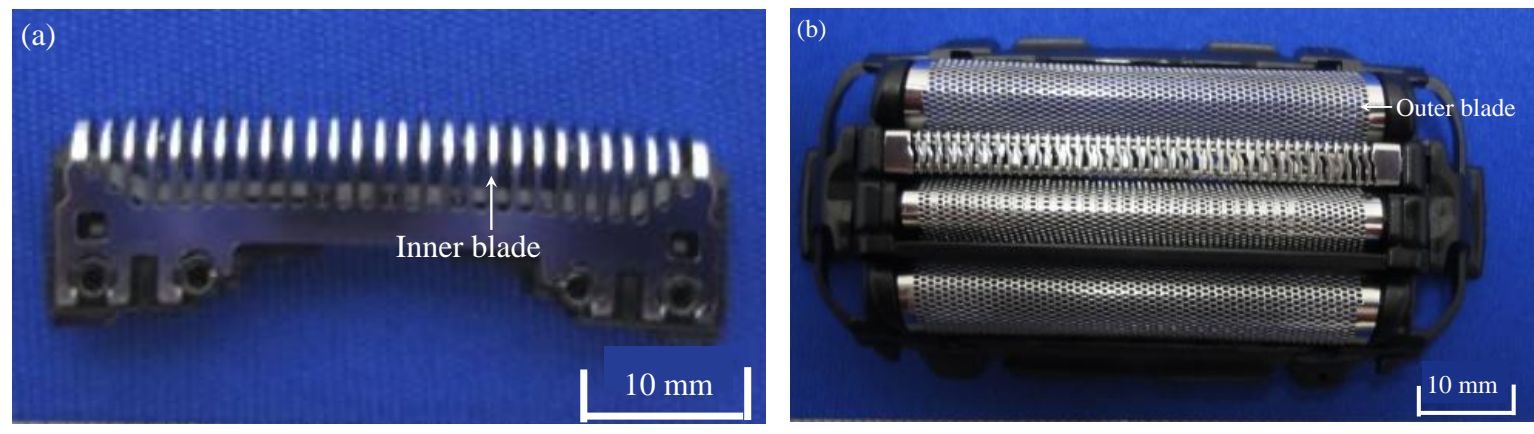

Fig. 3 The picture of oscillation type shaver of (a) inner blade and (b) outer blade. This type has arch shape inner blade which moves both way to cut the hair. The outer blade is like punching metal which has approximately $0.5 \mathrm{~mm}$ diameter of holes. The outer blade does not move when it cut hairs.
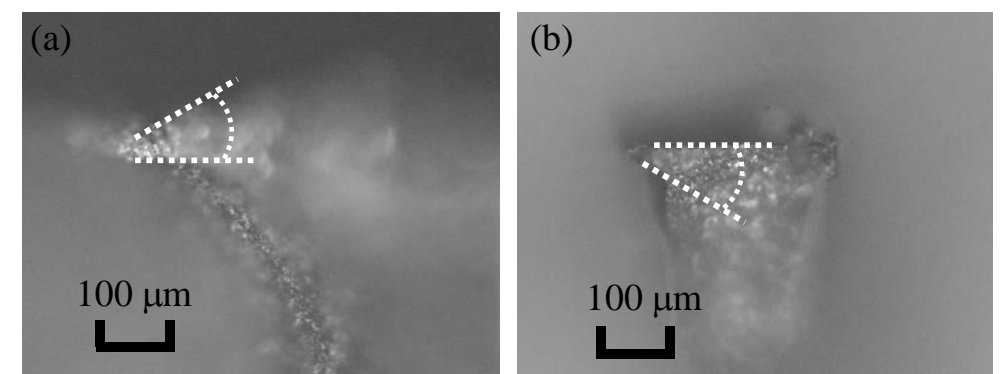

Fig. 4 The optical microscope image of inner blade as (a) rotation type shaver and (b) oscillation type shaver. Each inner blade tip angle is approximately 30 degree and the tip radius is approximately $11 \mu \mathrm{m}$. 
Table 1 The property values of nylon artificial hair

\begin{tabular}{l|c}
\hline Diameter $d, \mathrm{~mm}$ & 0.2 \\
\hline Strength $S, \mathrm{MPa}$ & 50 \\
\hline Young's modulus $E, \mathrm{MPa}$ & $400-600$ \\
\hline Melting point $t,{ }^{\circ} \mathrm{C}$ & 265 \\
\hline Specific gravity & 1.14 \\
\hline
\end{tabular}

\section{$2 \cdot 2$ 切断中の内刃撮影}

高速で作動しているシェーバーの内刃は高速度カメラにより撮影された．撮影には C-MOS イメージセンサー を搭載した FASTCAM SAX を用い撮影速度 10,000 FPS（FPS,フレームパーセコンド，コマ秒）で撮影した. 撮 影時に必要な光源としてメタルハライドファイバー照明（LS-M210）を用い，観察部を拡大して撮影できるよう に拡大用レンズ（VSZ-M07545）を用いた。映像の解析には，Photron FASTCAM Viewer ver.325を用いた。

\section{3. 実験結果}

\section{$3 \cdot 1$ 高速度カメラ撮影による往復式シェーバーの内刃速度の変化測定及び回転式シェーパー速度測定}

回転式シェーバーは一定速度にて回転して髭を切断するが，往復式の場合速度の変化が生じる．そこで，内刃 の速度変化を予め明らかにするため，高速度カメラを用いて内刃の観察を行い，内刃の位置及び計測時間から速

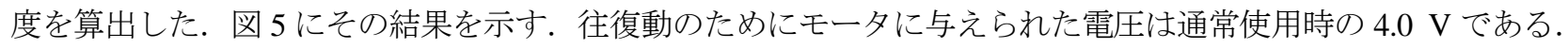
観察から刃先速度は $0 \mathrm{~m} / \mathrm{s}$ から最高速度約 $2.3 \mathrm{~m} / \mathrm{s}$ ，ストローク約 $5 \mathrm{~mm}$ が得られ，この最高速度は内刃振幅のほ ぼ中央付近で得られていた。一方, 回転式シェーバーの場合, 回転速度は高速度力メラ撮影から $2200 \mathrm{rpm}$ である ことが明らかにされ，内刃の速度を回転半径から算出した結果，約 $1.15 \mathrm{~m} / \mathrm{s}$ であることが明らかとなった.

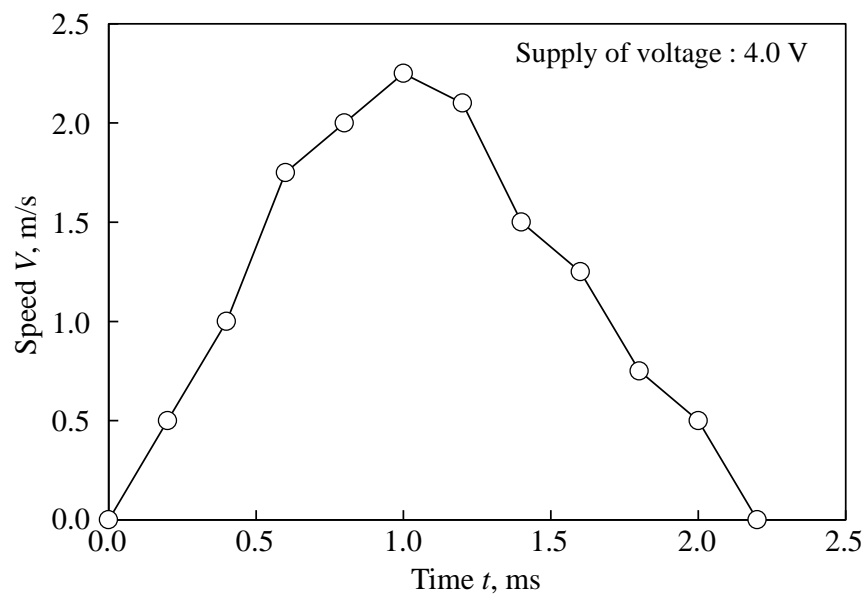

Fig. 5 The oscillation type shaver inner blade speed was measured by high speed camera. Supply voltage to the motor was ordinary using $4.0 \mathrm{~V}$. The minimum speed was $0 \mathrm{~m} / \mathrm{s}$ and the maximum speed was approximately $2.3 \mathrm{~m} / \mathrm{s}$.

\section{$3 \cdot 2$ 各動作方式による人工毛切断実験結果}

往復式シェーバーを用いて人工毛を切断した際の人工毛がシェーバー内に引き込まれる際の力を測定した結果 の代表例を図 6 （a）に示す.また，図中に示す主な部分の高速度カメラ撮影画像を図 6 (b) 〜 (d) に示す. 内 刃が人工毛に接触する前の状態では図 6 (a) 内の矢印（b）に示すように，引き込み力は 0 を示している. その 後測定経過時間約 $6 \mathrm{~ms}$ にて引き込み力が正方向に増加している部分で人工毛と内刃が接触した. 測定経過時間が 
約 $10 \mathrm{~ms}$ において一度引き込み力はピークを迎え，やや引き込み力が減少する傾向が明らかにされているが，内 刃が人工毛に接触してすぐに人工毛を完全に切断できておらず，人工毛に内刃が接触した状態で外刃に向かって 共に移動している状態を示している，測定経過時間が約 $15 \mathrm{~ms}$ で人工毛及び内刃は外刃に接触し始め，引き込み 力が増加し始める. 図中 (c) で示した最大引き込み力発生時の観察写真から, 内刃と外刃の間に人工毛が挟まり, 完全に切断する直前であることが明らかである. 高速度カメラ観察から, 内刃は必ずしも動作しておらず，人工 毛に接触して停止している時間が多く観察された．測定経過時間約 $22 \mathrm{~ms}$ 以降においても引き込み力が測定され ている理由は，切断時に引きちぎられた人工毛が，シェーバー内に残されており（図７に著者らが以前取得した 人工毛の良く切れている状態と引きちぎられた状態の写真を示す (Tokoroyama et al., 2007)), この部分を複数回 内刃が接触して切断しているためであることが，観察から明らかにされた（図７（c）に模式図を示す）．上記の 実験を繰り返し行い, 7 回の実験で同様の挙動が観察され, 得られた最大の引き込み力は約 $0.15 \mathrm{~N}$, 各実験の最 大值の平均值は $0.04 \mathrm{~N}$ であった.

切断後の断面を ESEM により観察した画像を図 8 に示寸. 切断面には大きく分けて二つの領域が観察された. 内刃が人工毛に接触した際に形成されたと考えられる塑性変形部及び内刃及び外刃に挟まれて切断された部分が あり，塑性変形により形成された断面は表面の凹凸が小さいことが SEM 写真のコントラストの無さから明らか である. 一方, 内刃及び外刃により切断された部分は表面に塑性流動したような（図中 shearing と記載部分）筋 状のコントラストが観察されている，後述する回転式の場合，一方向のみに内刃が移動しているため，塑性変形 痕は一か所のみに形成されるが, 往復式の場合, 一度の刃先の移動で完全に切断されない場合に図 8 に示すよう な人工毛の両側に塑性変形痕が観察されている.

次に回転式シェーバーを用いて人工毛を切断した際の人工毛がシェーバー内に引き込まれる際の力を測定した 結果を図 9 (a) に示寸. また, 図中に示寸主な部分の高速度カメラ撮影画像を図 9 (b) 〜 (d) に示寸. 内刃が 人工毛に接触する前の状態では図 9 （a）内の矢印（b）に示すように，引き込み力は 0 を示している. その後測 定経過時間約 $10 \mathrm{~ms}$ にて引き込み力が正方向に増加している部分で人工毛と内刃が接触し, 人工毛に内刃が接触
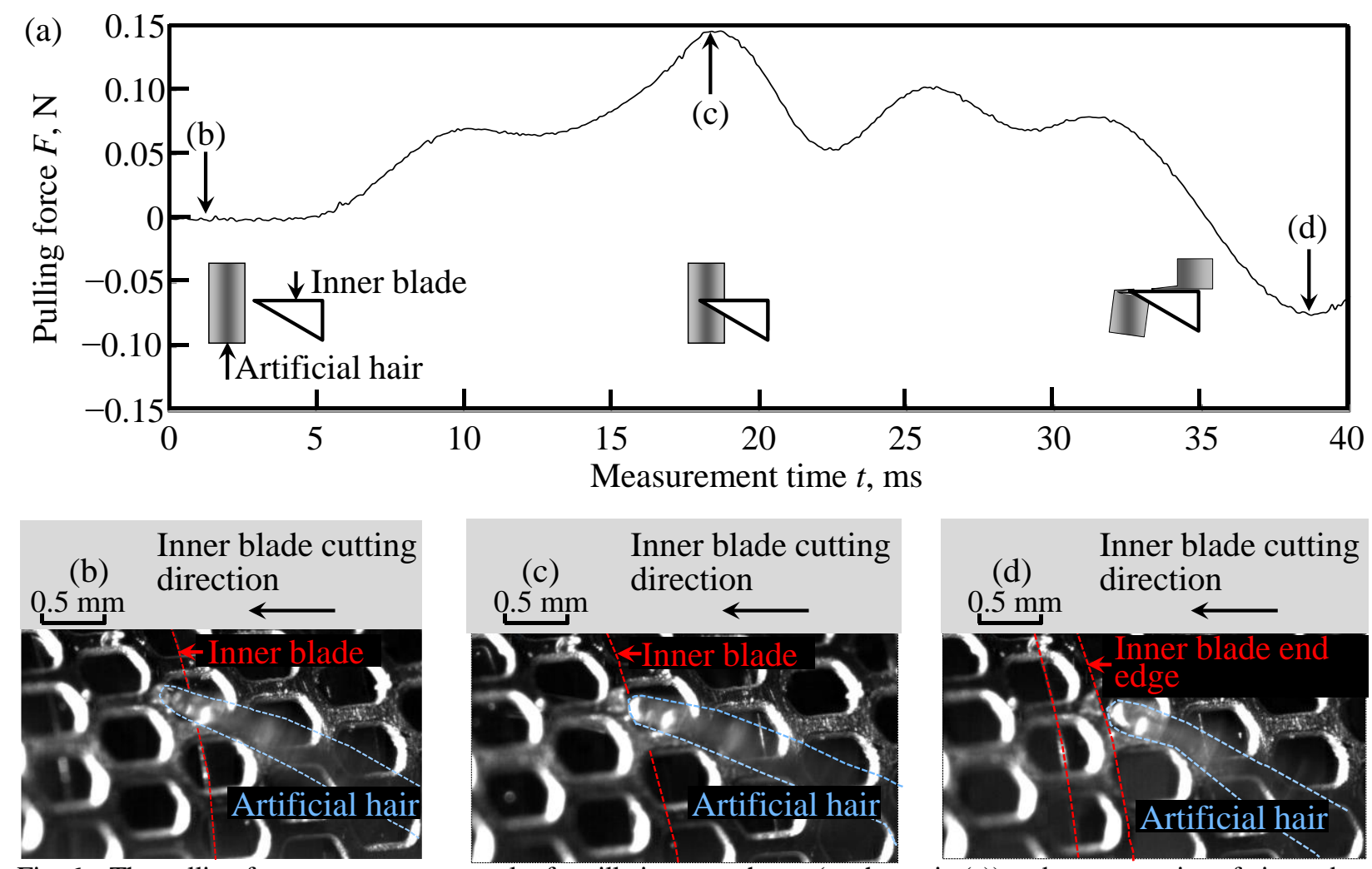

Fig. 6 The pulling force measurement result of oscillation type shaver (as shown in (a)) and representative of picture by high speed camera (as shown in (b) to (d)). First of all, from 0 to applox. 5 ms showed $0 \mathrm{~N}$ which meant non-contact situation. The maximum pulling force was measured at (c), which was explicit to the verge of shearing the artificial hair completely. After the peak value of pulling force, several pulling force was measured because of residual artificial hair which extended by shearing existed. 
した状態で外刃に向かって共に移動している状態を示している. 測定経過時間が約 $15 \mathrm{~ms}$ で最大引き込み力が発 生しており (c)，この時内刃と外刃の間に人工毛が挟まり，完全に切断する直前であることが明らかである．こ の実験も 7 回繰り返し行った結果，最大引き込み力は約 $0.13 \mathrm{~N}$, 平均值は $0.03 \mathrm{~N}$ であった. 往復式に比べいずれ も低い值が得られた．この原因の一つとして傾斜切削が考えられる. 回転式シェーバー内刃は図 2(a) に示寸よ うに回転方向から約 60 90 $90^{\circ}$ 傾いて刃が付いており, 人工毛に衝突する際には刃先が人工毛を引き切りする状態 となるものと推測される，一般的に有効すくい角が大きい場合には加工合力が減少する傾向にあり，刃先角度の 影響により切断時の引き込み力が減少したものと考えられる（社本, 2002). ただし, 傾斜切削では切削幅が傾斜 しない場合に比べ小さくなることから加工合力は減少するが，切断までの距離は長くなるため加工に使用される エネルギは等価と考えられる. 切断後の断面を ESEMにより観察した画像を図 10 に示す. 切断面には大きく分 けて二つの領域が往復式の場合と同様に観察され, 内刃が人工毛に接触した際に形成されたと考えられる塑性変 形部及び内刃及び外刃に挟まれて切断された部分があった. 往復式と異なる点は一方向のみの回転により人工毛 が切断されているため, 塑性変形痕は一か所のみに形成されていた. 内刃及び外刃により切断された部分は表面 に塑性流動したような筋状のコントラストが観察されていた。

(a) Cut-well

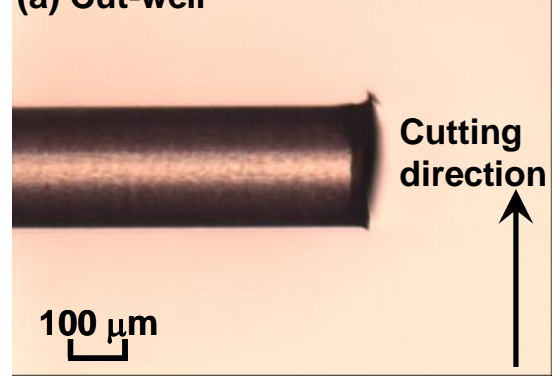

(b) Cut-worse

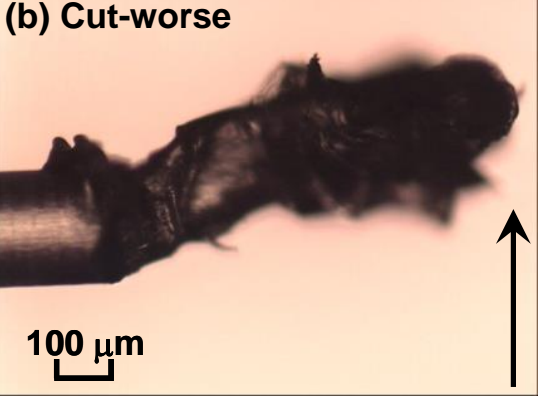

(c)

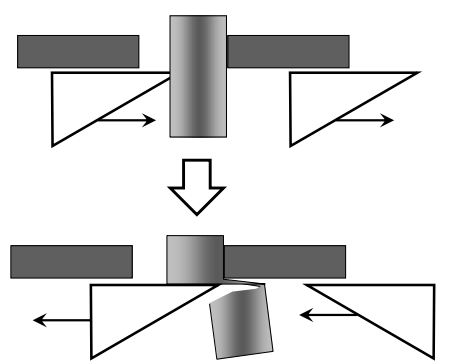

Fig. 7 The optical microscope image of (a) cut-well and (b) cut-worse by rotary type shaver. (Tokoroyama et al., 2007), and (c) schematic image of cut-worse artificial hair in oscillation type shaver.

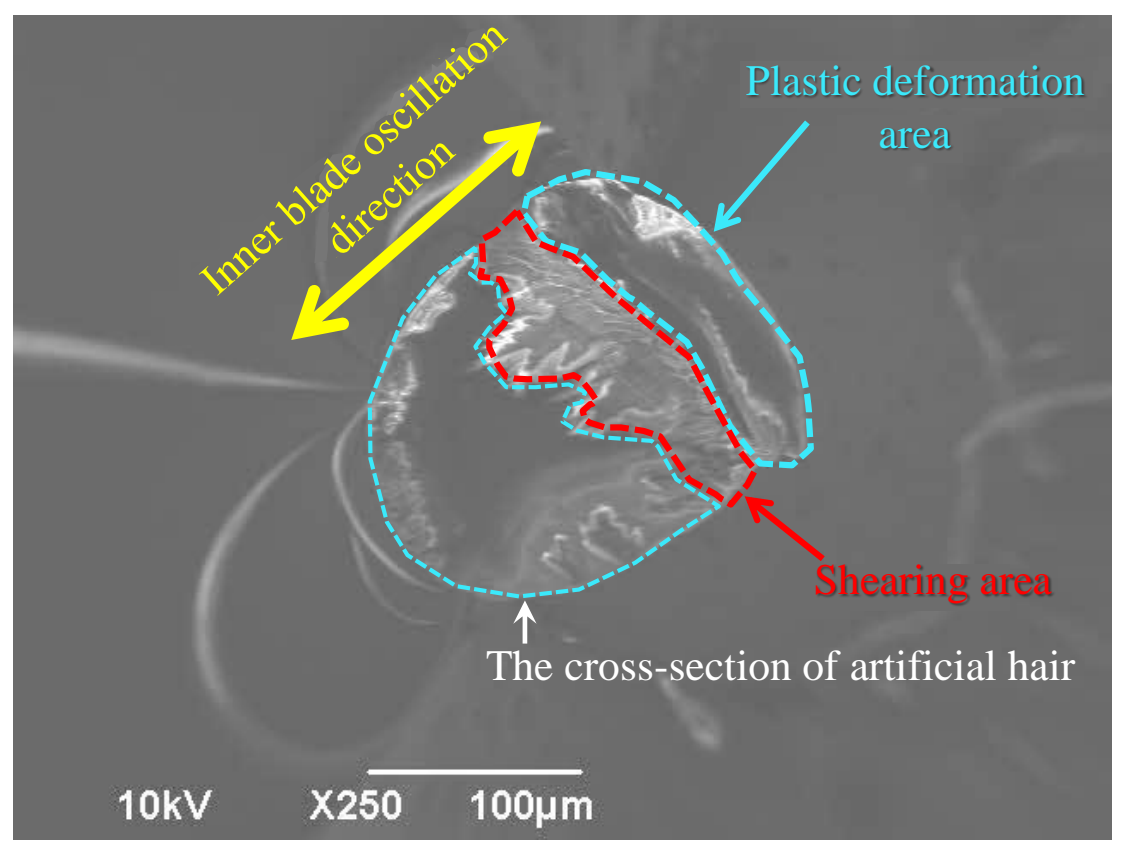

Fig. 8 The ESEM observation of after cutting artificial hair's cross-section image (oscillation type shaver). The cross-section mainly consisted of two area. One was plastic deformation area, and the other was shearing area. The plastic deformation area was formed by inner blade contact to the artificial hair. On the other hand, the shearing area was formed by scissor action by inner and outer blade. The picture clearly showed the existence of not only one path cut but also inner blade contacting several times. 

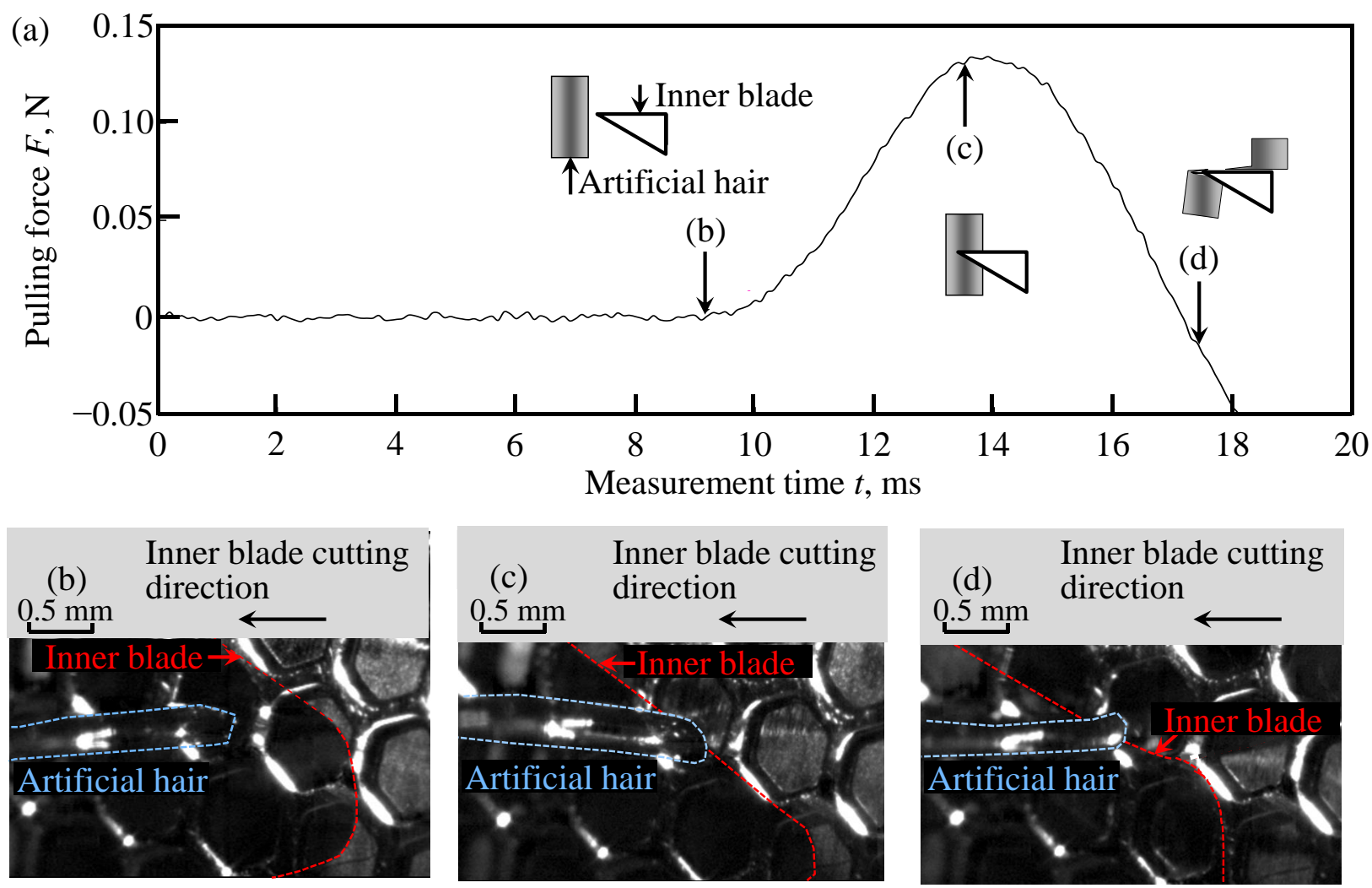

Fig. 9 The pulling force measurement result of rotary type shaver (as shown in (a)) and representative of picture by high speed camera (as shown in (b) to (d)). First of all, from 0 to applox. 9 ms showed $0 \mathrm{~N}$ which meant non-contact situation. The maximum pulling force was measured at (c), which was explicit to the verge of shearing the artificial hair completely. After the peak value of pulling force.

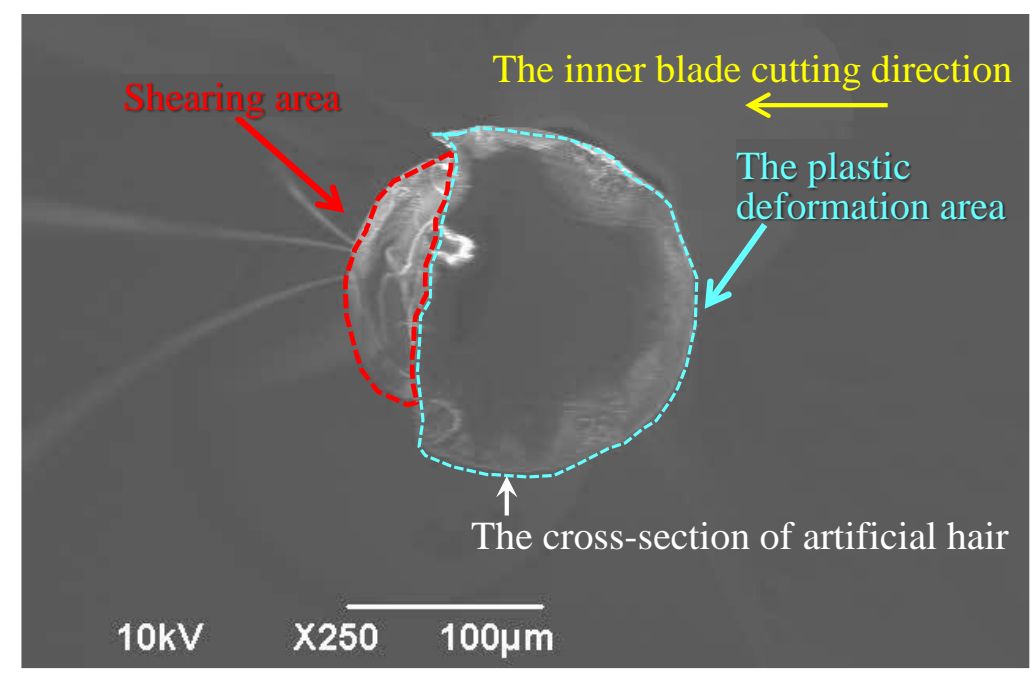

Fig. 10 The ESEM observation of after cutting artificial hair's cross-section image (rotary type shaver). The cross-section mainly consisted of two area. One was plastic deformation area, and the other was shearing area. The plastic deformation area was formed by inner blade contact to the artificial hair. On the other hand, the shearing area was formed by scissor action by inner and outer blade.

\section{$3 \cdot 3$ 回転式シェーパーの刃先速度が引き込みカに及ぼす影響}

回転式シェーバーの内刃回転速度が引き込み力の及ぼす影響を明らかにするために異なる電圧及び電流值でモ

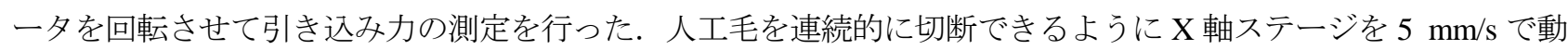
作させ，人工毛を挿入し続けながら実験を行った. 刃先速度はそれぞれ平均で $0.68,0.79,0.95,1.09$ 及び $1.18 \mathrm{~m} / \mathrm{s}$ である. 得られた結果を図 11 に示す. 回転速度の増加に伴い引き込み力の平均值及び最大值と最小值の幅が減少 


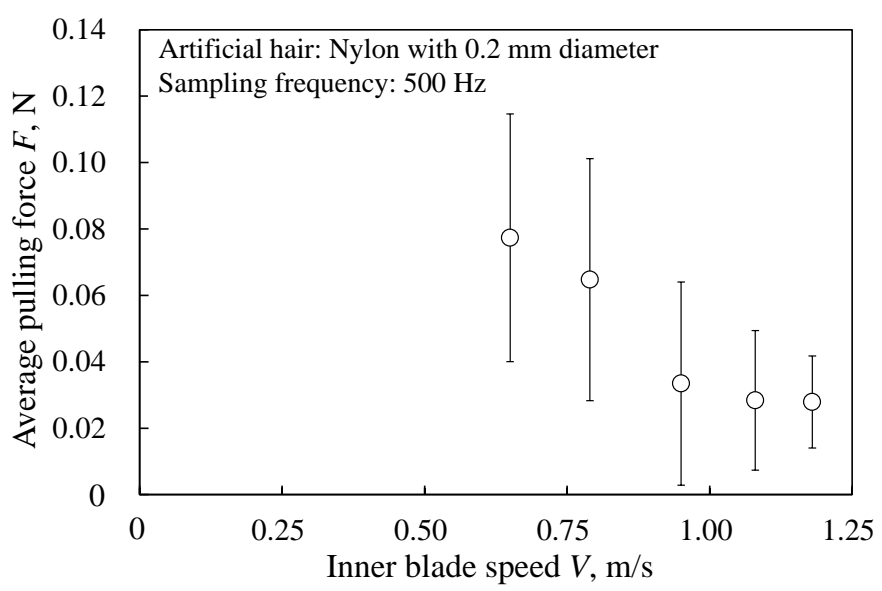

Fig. 11 The average pulling force as a function of inner blade speed of cutting an artificial hair. The speed was approx. $0.68,0.79,1.09$ and $1.18 \mathrm{~m} / \mathrm{s}$. The average pulling force and the amplitude of its force decreased with increasing inner blade speed.

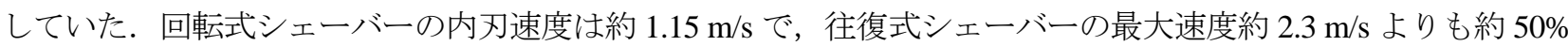
低速であるにも関わらず，切断時に発生する引き込み力は往復式の場合の最大值約 $0.15 \mathrm{~N}$, 平均值約 $0.04 \mathrm{~N}$ に比 べてともに小さいことが明らかになった。

\section{4. 考察}

\section{4-1 切断形態と引き込み力発生原因}

往復式及び回転式シェーバーのいずれにおいても，シェーバー内部方向一髭を引き込む力が発生している。い ずれの場合も図 12 （a）から（d）の模式図に示すように内刃が人工毛に衝突して突き刺さり，その後外刃との間 に挟み込んで切断していることが高速度カメラ観察から明らかである. 人工毛に突き刺さった状態の内刃と人工 毛は外刃に向かって移動し, 最終的にはさみの切断と同様の動作にて人工毛を切断している（井上他，2006）. こ の切断の際に, シェーバー内部へと引き込む方向へ力が発生している. 往復式の場合, 内刃が複数回人工毛に衝 突していることが明らかにされ（図 6 及び 8), 切断形態として示した図 12 (d) のはさみによる切断と同様の形 態にて未切断となる䯿が多数存在するものと予想される. そのため, 平均的に往復式シェーバーが回転式に比べ 引き込み力が大きくなるものと考えられる.

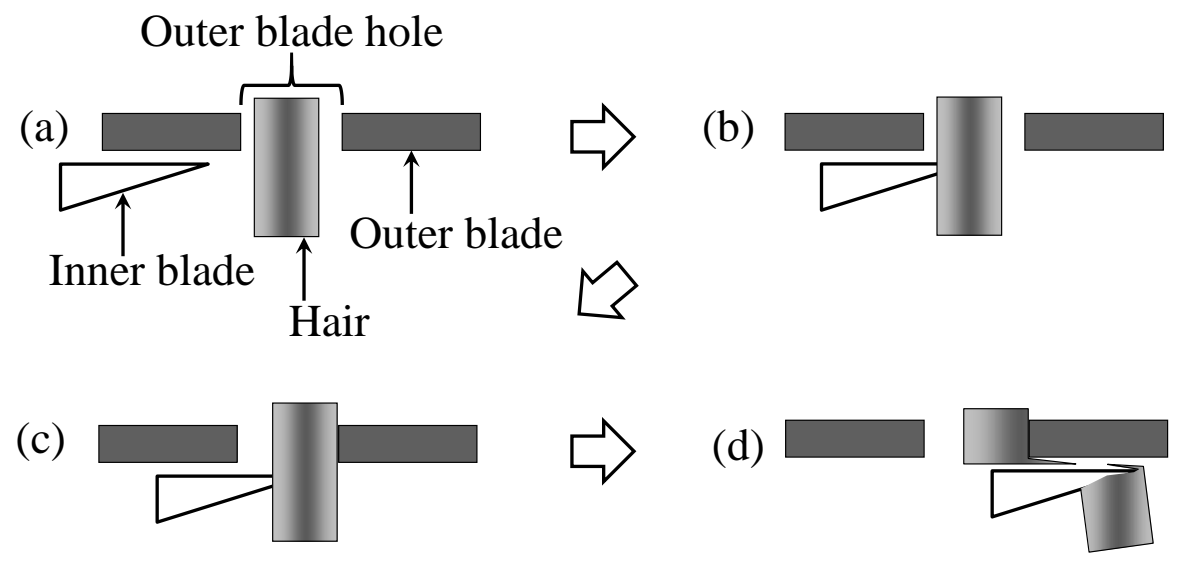

Fig. 12 The schematic images of cutting hair by inner and outer blade. (a) Before the inner blade crashed to the hair. The hair existed through outer blade hole from face side to inside of shaver. (b) The inner blade crashed and the tip penetrated into the hair with plastic deformation of it. (c) The inner blade and the hair moved together on the direction of outer blade. (d) The hair was cut by scissor action by inner and outer blade generated pulling force. 


\section{5. 結 言}

往復式及び回転式シェーバーの髡切断形態を明らかにするため, 高速度カメラを用いて内刃による人工毛の切 断時観察を行った. また，同時に人工毛がシェーバー内に引き込まれる力を測定し，往復式及び回転式の違いが 引き込み力に及ぼす影響について明らかにした．また，回転式シェーバーの内刃速度が引き込み力に及ぼす影響 について明らかにした。得られた主な結果を以下に示す。

（1）往復式及び回転式のいずれの方式においても，人工毛に内刃が衝突し，人工毛を塑性変形させていること が示され，また切断時には人工毛を引きちぎるように切断していることが明らかとなった.

（2）往復式の場合, 鬖に内刃が複数回衝突していることが明らかにされた. 往復式の場合の最大引き込み力は 約 $0.15 \mathrm{~N}$, 平均值は $0.04 \mathrm{~N}$ であるのに対し, 回転式の場合最大值約 $0.13 \mathrm{~N}$, 平均值 $0.03 \mathrm{~N}$ と低い值であることが 示された.

（3）回転式シェーバーの回転速度と引き込み力の関係から, 低回転速度（ $0.68 \mathrm{~m} / \mathrm{s})$ では引き込み力の最大值が 大きく, 一般使用時の速度では $(1.18 \mathrm{~m} / \mathrm{s})$ 引き込夕力の最大值及び平均值が減少した. また, 往復式の内刃速度 $2.3 \mathrm{~m} / \mathrm{s}$ に比べ，回転式の場合約 $50 \%$ の速度であるにも関わらず，引き込み力が全体的に小さいことが示された.

\section{文献}

井上研司, 本村貢, 飯村崇, 園田哲也, 理美容はさみによる切断が毛髪に与える影響について, 日本塑性加工学 会誌, Vol.47, No.541 (2006), pp.139-143.

日本工業規格，JIS C 9614-1995，電気かみそり（1995）．

景山元裕，飯村兼一，毛髪のトライボロジー，トライボロジスト，Vol.54，No.6（2009）, pp.377-382.

佐藤直紀，美しい髪の機構と毛髪構造，表面科学，Vol.27, No.8 (2006), pp.480-484.

社本英二, 3 次元切削機構に関する研究（第 1 報）-傾斜切削プロセスの理解とベクトルによる定式化-, 精密工学 会誌, Vol.68, No.3 (2002), pp.408-414.

Tokoroyama, T., Mohd, N. and Umehara, N., Evaluating shaver sharpness by measuring the pulling force on artificial hair, Journal of Advanced Machanical Design, Systems, and Manufacturing, Vol.1, No.5 (2007), pp.661-668.

\section{References}

Inoue, K., Motomura, M., Iimura, T. and Sonoda T., Effect of cutting quality of hair-cutting scissors on human hair, Journal of the Japan Society for Technology of Plasticity, Vol.47, No.541 (2006), pp.139-143 (in Japanese).

Japanese Industrial Standards, JIS C9614-1995, Electric shavers (1995) (in Japanese).

Kageyama, M. and Iimura, K., Tribology in human hair, Journal of Japanese Society of Tribologists, Vol.54, No.6 (2009), pp.377-382 (in Japanese).

Sato, N., Mechanism of beautifulness of hair and the structure factors, Journal of the Surface Science Society of Japan, Vol.27, No.8 (2006), pp.480-484 (in Japanese).

Shamoto, E., Study on three dimensional cutting mechanics ( $1^{\text {st }}$ Report $)$-Comprehension and vector formulation of oblique cutting process-, Vol.68, No.3 (2002), pp.408-414 (in Japanese).

Tokoroyama, T., Mohd, N. and Umehara, N., Evaluating shaver sharpness by measuring the pulling force on artificial hair, Journal of Advanced Machanical Design, Systems, and Manufacturing, Vol.1, No.5 (2007), pp.661-668. 